\title{
Chapter 6 \\ The Multiple Factors Explaining Decline in Mountain Forests: Historical Logging and Warming-Related Drought Stress is Causing Silver-Fir Dieback in the Aragón Pyrenees
}

\section{J. Julio Camarero}

\begin{abstract}
The drivers and patterns of drought-related forest dieback are not as well understood in mountain conifer forests. Most studies have obviated the role of historical use as a predisposing factor of forest dieback. Here I focus on the recent silver-fir (Abies alba) dieback observed since the 1980s in the Aragón Pyrenees (NE Spain) as study case. I argue that such dieback was predisposed by past historical logging and incited by warming-induced drought. I analyzed environmental, structural and tree-ring data from 32 sites with contrasting degrees of dieback at the tree and stand levels. I found that a peak in late-summer water deficit observed in 1985 caused a severe growth reduction in 1986, resulting in subsequent crown defoliation, dieback and increased mortality. Dieback was more severe and widespread in western low-elevation mixed forests dominated by smaller trees with low growth rates. These marginal sites receive less late-summer rainfall, which is a key climatic variable controlling silver-fir growth, than eastern sites. Declining sites showed more frequent growth releases induced by historical logging than non-declining sites. Silver-fir growth is becoming more dependent on climatic conditions of previous September, which may be connected with changing modes of atmospheric variability affecting Iberian climate. Historical logging and warming-induced drought stress during late summer are the most likely predisposing and inciting factors driving silver-fir dieback, respectively. A sustainable management of mountain forests shaped by past historical use requires changing their current structure and composition to make them more resilient to climate warming.
\end{abstract}

Keywords Abies alba - Climate warming - Dendroecology • Radial growth • Releases

J.J. Camarero $(\bowtie)$

Instituto Pirenaico de Ecología (IPE-CSIC), Avda. Montañana 1005,

50192 Zaragoza, Spain

e-mail: jjcamarero@ipe.csic.es

(C) The Author(s) 2017

J. Catalan et al. (eds.), High Mountain Conservation in a Changing World,

Advances in Global Change Research 62, DOI 10.1007/978-3-319-55982-7_6 


\subsection{Introduction}

Forests store almost half of terrestrial carbon, but the long-term net carbon uptake by forests is a slow process mainly controlled by the growth rate of woody tissues (Bonan 2008). Contrastingly, huge carbon emissions may occur rapidly from sudden or widespread mortality episodes often preceded by forest dieback and growth decline (Breshears and Allen 2002). In water-limited regions, climate warming may intensify drought stress and lead to growth decline and forest dieback (Allen et al. 2010, 2015). This dieback phenomenon is linked to rapid defoliation and selective mortality of overstory trees (McDowell et al. 2008). However, in mountain and temperate forests, the factors causing forest dieback under more mesic conditions are not as well understood (van Mantgem and Stephenson 2007).

Mountains are characterised by: (i) a high heterogeneity in local climate conditions which change over short distances as a function of altitude and topography and create steep ecological gradients (Barry 2008), and (ii) by preserving large forested areas subjected to an extended historical management, particularly in Europe (Kirby and Watkins 1998). It is predicted for the twenty-first century a greater warming in the mountains than in the lowlands of the Northern Hemisphere (Kohler et al. 2014). Mountain forests face climatic gradients which limit their productivity, cold stress towards the uppermost treeline but also drought stress downwards, and make them sensitive to climate warming but also to changes in management. The management and use of these forests in Europe have changed rapidly during the past century. Mountain forests provide many ecosystem services (carbon uptake, regulation of water cycles, protection from snow avalanches, biodiversity conservation, etc.) but they also represent a source of timber, biomass for energy production and non-woody goods (e.g. mushrooms, hunting). During the twentieth century, timber extraction was still profitable in some European forests as those formerly exploited at the Spanish Pyrenees (Cabrera 2001). However, currently, many of these mountain forests are not managed for timber production because commercial forestry is no longer profitable. In this chapter, I explore how changes in historical management interact with climate warming and intensified drought stress to trigger dieback in mountain forests.

Here I argue that the historical use of forests strongly interacts with current climatic trends as the rise in temperatures to determine the current fate of forests, which in some case can jeopardise its future. I will illustrate how past historical logging and recent warming-related drought stress contribute to silver-fir dieback in Pyrenean mountain forests subjected to mesic conditions. The processes leading to forest dieback are still poorly understood because of the interaction of several stress factors acting at different spatiotemporal scales, which complicates the disentangling of lagged cause-effect relationships (Pedersen 1999). Many dieback episodes have been studied following Manion's (1981) conceptual model, which includes predisposing, inciting and contributing stress factors causing a loss in tree vigour. Predisposing factors such as site conditions reduce a tree's vigour over the long term (Suarez et al. 2004), whereas inciting factors such as drought lead to a sharp 
and short-term reduction in tree growth and vitality (Bigler et al. 2006). Other factors (mainly pathogens and insects) may contribute to dieback acting as secondary stress factors. According to this model, the most sensitive trees to short-term inciting stress factors will be those that were previously most strongly weakened by long-term predisposing factors. Here I use this conceptual model to assess the roles played by long-term predisposing (historical management) and short-term inciting (drought stress) factors as drivers of dieback in mountain forests.

Most studies on forest dieback have obviated the potential role of historical land use (e.g. past logging) as a predisposing factor (but see Linares et al. 2009). Furthermore, the different nature of interacting factors such as land-use legacies (e.g. past logging) and climatic extremes (e.g. severe droughts) have precluded considering the interactions between them. In Europe, historical effects have persisted for decades and centuries shaping the current structure of most mountain conifer forests (Kirby and Watkins 1998). Therefore, past forest use should be considered as an additional driver of dieback and its role should be assessed.

Here I focus on dieback episodes of silver-fir (Abies alba Mill.) forests reported since the 1980s in the Western and Central Spanish Pyrenees (Navarra and Aragón Pyrenees; see Fig. 6.1), near the south-western limit of the species' distribution area (Camarero et al. 2002). Silver-fir dieback has been systematically reported in the 1970s and 1980s across central Europe (Skelly and Innes 1994). In the Aragón Pyrenees silver-fir dieback was more severe in western stands located at medium elevation than in eastern high-elevation sites. In the most affected stands, up to $30-50 \%$ of trees showed severe defoliation, which was related to the occurrence of severe summer droughts in the 1980s (Camarero et al. 2002). Therefore, it may be hypothesised that drought stress has recently increased by climate warming and precipitation regime shifts causing silver-fir dieback. In addition, most of these forests were logged to extract timber up to the 1970s when their management ceased due to rural migration to cities (Cabrera 2001). So, it remains to be answered if those forests that were more intensively logged in the past were also more predisposed to drought-triggered dieback during the 1980s and more recently. In this study, I address the following questions: (1) How did silver-fir growth change in the Aragón Pyrenees during the twentieth century and how was it affected by the recent patterns of defoliation? (2) Did historical logging and warming-induced drought cause the recent silver-fir dieback? To answer these questions, I will focus on the retrospective analyses of tree-ring data.

\subsubsection{Geographical and Climatic Backgrounds}

The Pyrenees constitute a transitional mountainous area between more humid conditions in their northern margin, where Eurosiberian vegetation is dominant, and drier conditions southwards (Vigo and Ninot 1987). This gradient overlaps with a similarly relevant longitudinal gradient caused by the location of the range between the Atlantic Ocean and the Mediterranean Sea. According to meteorological data 

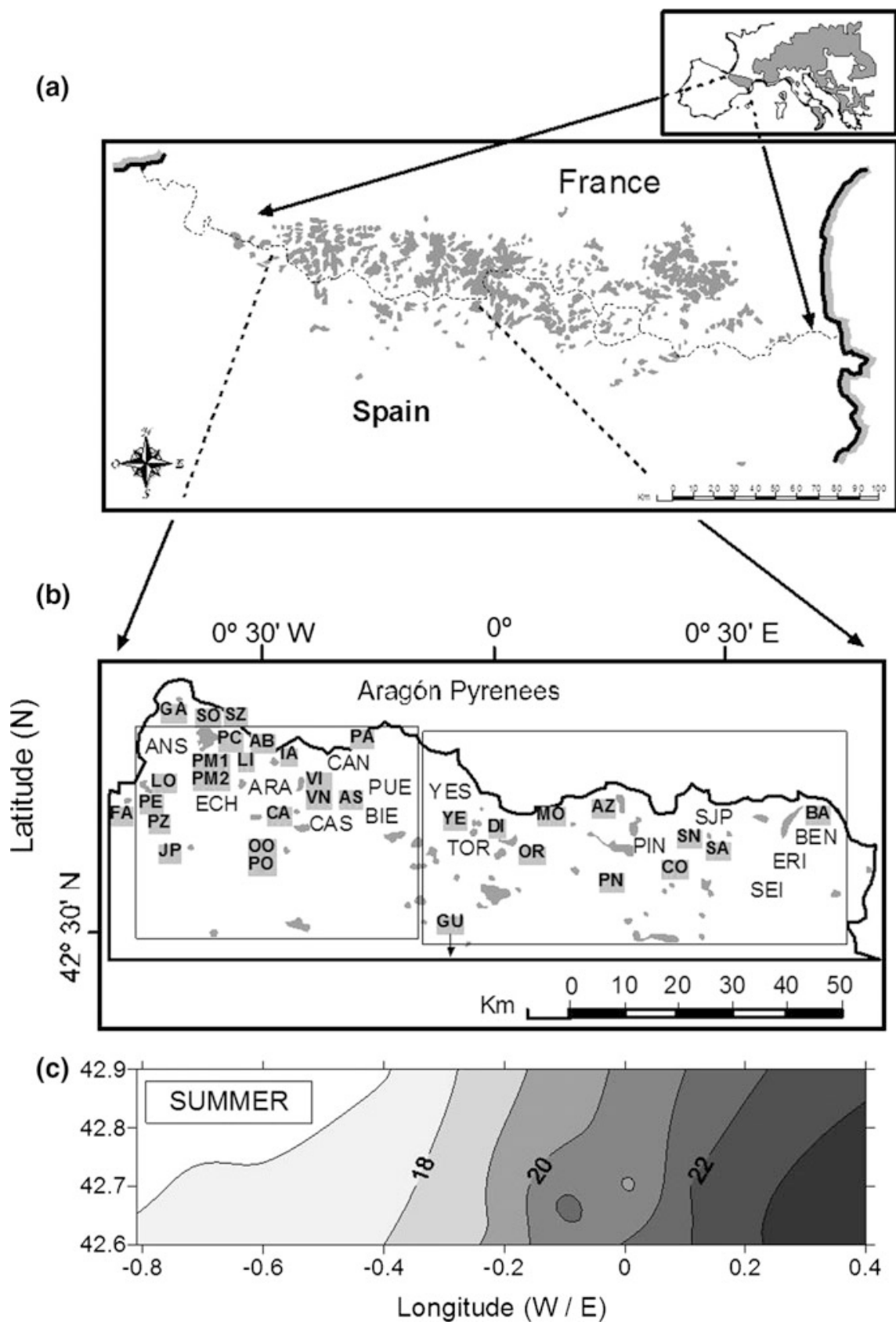
4Fig. 6.1 Geographical and climatic context of the study silver-fir forests. Distribution of silver fir in Europe (a) and study sites in the Aragón Pyrenees, northeastern Spain (sites' codes are indicated with bold letters) (b). The two rectangles in the lower figure delineate the two homogeneous climatic sub-regions based on local data from the displayed climatic stations (indicated by three-letter codes): Western (WAP) and Eastern (EAP) Aragón Pyrenees. c The longitudinal gradient of percent summer precipitation in the study area interpolated through kriging

from nearby stations, the climate in the study area can be described as continental with oceanic (western sites) or Mediterranean (eastern and southern sites) influences. The westward oceanic influence leads to greater precipitation in winter and a smaller temperature range than eastwards. This oceanic influence decreases eastwards where the Mediterranean influence prevails being characterised by higher precipitation in summer than westwards (Fig. 6.1c).

The studied silver-fir populations are located in the Aragón Pyrenees, NE Spain (Fig. 6.1; ca. $5600 \mathrm{~km}^{2}$ ). The main geographic and topographic characteristics of the 32 sampled stands are described in Table 6.1. In the Aragón Pyrenees, silver-fir stands are usually found at humid sites on north-facing slopes where they form pure or mixed stands with European beech (Fagus sylvatica L.) or Scots pine (Pinus sylvestris L.). Silver-fir forests in the study area may experience summer drought stress in August, despite they receive a total annual precipitation between 900 and $2000 \mathrm{~mm}$, which usually increases with elevation. Most studied stands are located on marls and limestones, which generate basic soils, or on moraine deposits with rocky but deep soils.

Because data from local meteorological stations are often inadequate to study the spatiotemporal variation of mountain climates, regional records averaging the longest and most complete local data available from the study area were created (see Camarero et al. 2011). I used monthly climatic data (mean temperature, total precipitation) to delineate two homogeneous and distinct climatic areas within the Aragón Pyrenees, hereafter abbreviated as WAP (western Aragón Pyrenees) and EAP (eastern Aragón Pyrenees) sub-regions. Mean temperature and precipitation data for each sub-region were obtained for the period 1940-1999. Finally, I calculated annual and cumulative monthly water deficits for both climatic sub-regions using a modified Thornthwaite water-budget procedure (see Camarero et al. 2011).

\subsubsection{Field Sampling}

Field sampling was conducted between 1999 and 2015. At least one site was sampled in each $10-\mathrm{km}^{2}$ grids covering the Aragón Pyrenees where silver-fir formed forests (Fig. 6.1). Because I was primarily interested in discerning the causes of forest dieback, more stands in the most affected areas were sampled (e.g. Camarero et al. 2015). In total, 21 and 11 sites were sampled within the WAP and EAP sub-regions, respectively, (Table 6.1). At each site, 10-15 dominant trees were selected for sampling within a 500-m long and $20-\mathrm{m}$ wide transect randomly 


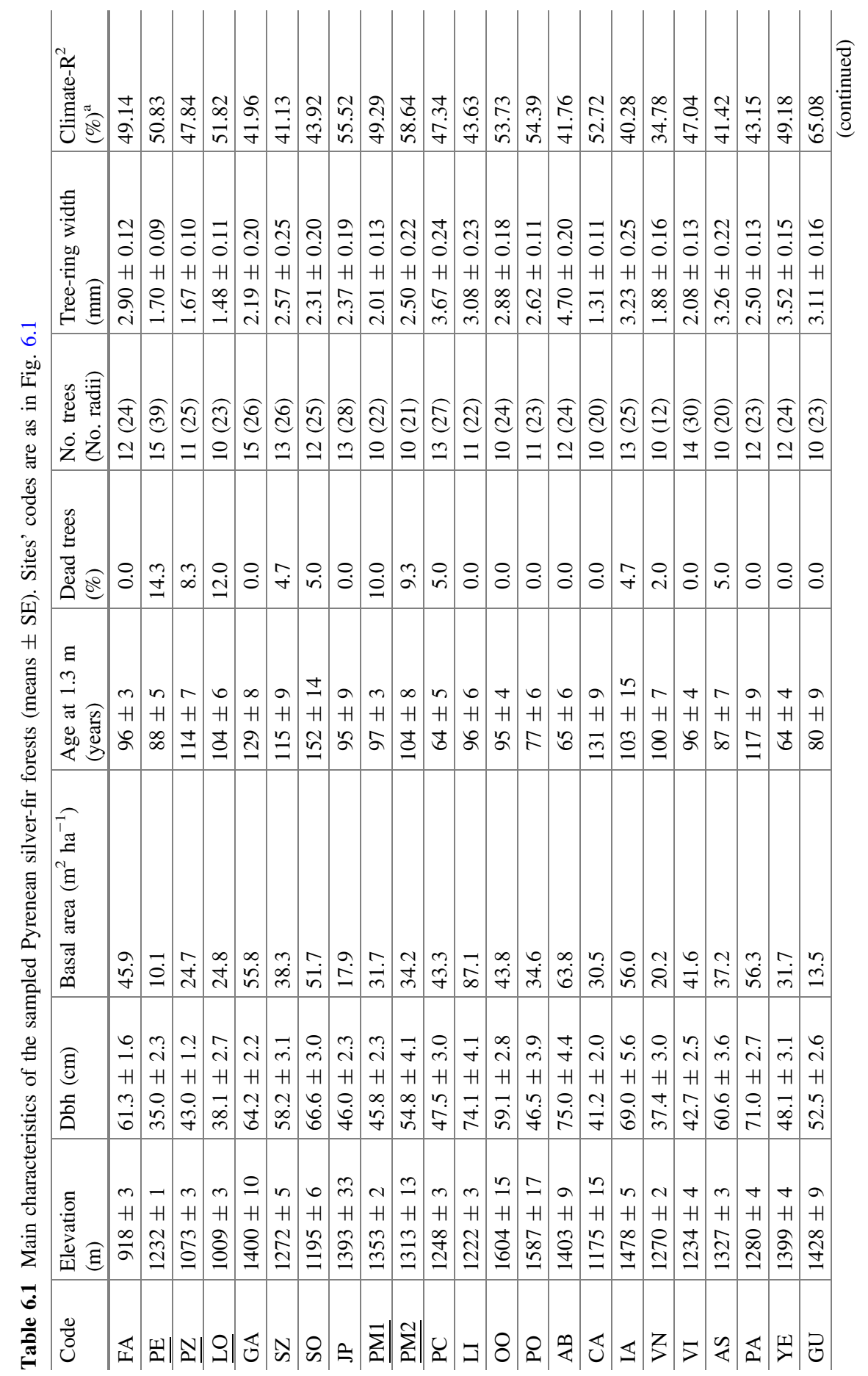




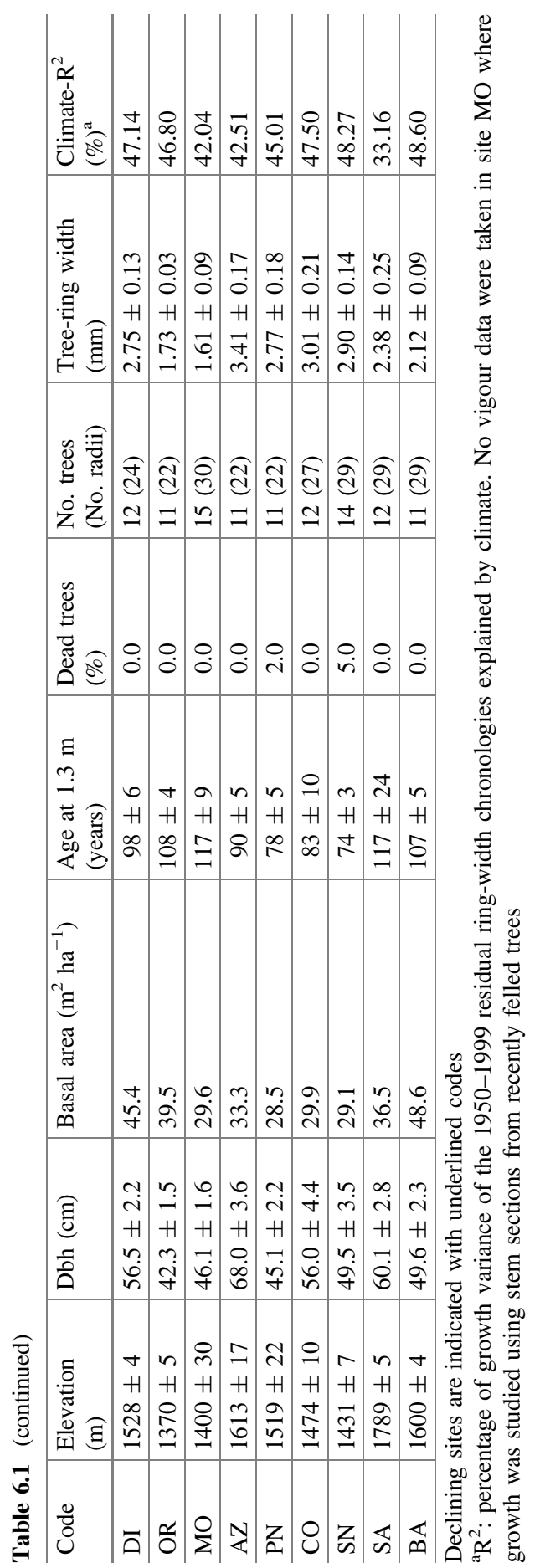


located within the stand. Several topographical variables were obtained for each site and tree. Elevation, aspect and slope steepness were measured at the tree level.

The diameter at $1.3 \mathrm{~m}$ (diameter at breast height, $\mathrm{dbh}$ ) of each tree located within the transect was also measured, and I assessed their vigour using a semi-quantitative scale based on the percentage of crown defoliation (Müller and Stierlin 1990): class 0, $0-10 \%$ defoliation (healthy tree); (1) 11-25\% (slight damage); (2) 26-50\% (moderate damage); (3) 51-75\% (severe damage); (4) 76-90\% (dying tree); (5) dead trees with $>91 \%$ defoliation or only retaining red needles. Since estimates of percent crown defoliation may vary among observers and places, I used as a reference a tree with the maximum amount of foliage at each site. Declining trees were considered as those with crown defoliation greater than $50 \%$, and declining sites were regarded as those with more than $25 \%$ trees with such degree of defoliation. Dead trees were regarded as those whose crowns showed complete defoliation or only retained red needles and whose most recently formed rings corresponded to years prior to the sampling year. Lastly, the number and dbh of all neighbouring trees found within a circular plot of $7.62 \mathrm{~m}$ in radius placed around each subject tree was measured to estimate the basal area $\left(\mathrm{m}^{2} \mathrm{ha}^{-1}\right)$ of the silver-fir neighbourhood. Values are given as means \pm standard errors throughout the text.

\subsubsection{Tree-Ring Data}

I followed established dendrochronological methods to analyse tree-ring data (Fritts 1976). Two or three cores were taken from each tree at breast height (1.3 m) using an increment borer. In the field, sapwood length was estimated visually whenever possible ( $n=92$ trees from 22 sites). The wood samples were air-dried and polished with a series of successively finer sandpaper grits. Then, wood samples were visually cross-dated. Tree rings were measured to the nearest $0.01 \mathrm{~mm}$ using a binocular scope and an LINTAB measuring device (Rinntech, Heidelberg, Germany). Cross-dating of the tree rings was checked using the program COFECHA (Holmes 1983). To calculate tree age at $1.3 \mathrm{~m}$, in the case of cores without pith, a geometric method based on the curvature of the innermost tree ring was used to estimate the missing distance to the pith. Stem sections and cores with pith $(n=120)$ were used to calculate regressions between the distance to the pith and the number of tree rings ( $r>0.98$ and $P<0.05$ in all cases).

The percentage growth change (GC) filter of Nowacki and Abrams (1997) was applied to identify abrupt and sustained increases or decreases in radial growth (i.e. releases or suppressions, respectively). First, I calculated the ring-width medians of subsequent 10 -year periods along all the growth series because medians are more robust estimators of central tendency than means. The M1 and M2 values are defined as the preceding and subsequent 10-year ring-width medians of a given dated ring, respectively. For instance, the periods M1 $=1946-1955$ and 
M2 = 1956-1965 are used to calculated the percentage growth change at the year 1955. The percentage of positive (PGC) and negative (NGC) growth changes were calculated in yearly increments as:

$$
\begin{aligned}
\mathrm{PGC} & =[(\mathrm{M} 2-\mathrm{M} 1) / \mathrm{M} 1] \cdot 100 \\
\mathrm{NGC} & =[(\mathrm{M} 1-\mathrm{M} 2) / \mathrm{M} 2] \cdot 100
\end{aligned}
$$

Growth releases were then defined as those periods with at least five consecutive years showing PGC values greater than $75 \%$.

Basal area increment (BAI, $\mathrm{cm}^{2}$ year ${ }^{-1}$ ) is assumed to be a more meaningful indicator of tree growth than tree-ring width because it removes variation in growth attributable to increasing circumference. Therefore, ring widths were converted to BAI assuming a circular outline of stem cross sections and using the formula:

$$
\mathrm{BAI}=\pi\left(R_{t}^{2}-R_{t-1}^{2}\right)
$$

where $R$ is the radius of the tree and $t$ is the year of tree-ring formation. In dominant trees, BAI series usually show an early phase of low growth followed by a rapid increase and a final stable phase. Mean annual values of tree-ring width, growth change and BAI were obtained for declining and non-declining sites throughout the twentieth century.

\subsubsection{Climate-Growth Analyses}

To assess the growth-climate relationships, a tree-ring width chronology was established for each site (Table 6.1). For each tree, its ring-width series was double detrended using a negative linear or exponential function and a cubic smoothing spline with a $50 \%$ frequency response cutoff of 30 years to preserve high- and medium-frequency variability. A spline flexible enough to maximise the tree-to-tree shared growth variance and its response to climatic variability was selected following Macias et al. (2006). Autoregressive modelling was performed on each detrended ring-width series, which were finally averaged using a biweight robust mean to obtain residual site chronologies. All chronologies were built using the program ARSTAN (Cook and Krusic 2005). All further climate-growth analyses were performed using residual chronologies. The spatial and temporal relationships among these site chronologies for the period 1900-1999 were summarised using Principal Component Analysis (PCA).

I calculated 32 correlation functions relating each site chronology to the corresponding sub-regional climate dataset for the period 1950-1999. Climate-growth relationships were calculated using monthly mean temperature and total precipitation from the previous January up to September of the growth year. 
Finally, to summarise these results and to define the main climatic response of declining versus non-declining sites, I performed a PCA on the matrix of the correlation function coefficients.

\subsection{Warmer Climate Conditions and the 1980s Peak in Water Deficit}

Overall, the climate is becoming warmer in the study area with a peak in drought stress during the 1980s. A strong warming trend was observed in the WAP during the late 1940s and in the 1980s (Fig. 6.2a). Precipitation decreased in the 1980s and increased during the 1960s. Furthermore, the relative contribution of summer rainfall to the total annual precipitation has significantly declined in the WAP area during the last half of the twentieth century (trend $=-0.09 ; P<0.01$ ). The mean annual water deficit during the 1940-1999 period was significantly higher in the WAP $(82.3 \pm 8.3 \mathrm{~mm})$ than in the EAP $(49.6 \pm 7.0 \mathrm{~mm})$ sub-region. The estimated annual water deficit peaked in 1985 and 1967 in both sub-regions but always reaching a greater annual deficit in the WAP sub-region than eastwards (Fig. 6.2b).

\subsection{Structural Features of Silver-Fir Stands Presenting Dieback: Low Growth Rates}

Most sites showing severe defoliation and dieback were located in the WAP sub-region at mid elevation (Table 6.1; Fig. 6.3b). These stands were dominated by silver-fir trees with low dbh and ages ranging 90-155 years old and corresponded to mixed forests with a low basal area. On average, we found a significantly higher frequency (Mann-Whitney test, $U=7.5, P<0.001$ ) of dead trees in declining $(10.8 \pm 1.1 \%)$ than in non-declining sites $(1.9 \pm 0.4 \%$; Table 6.1$)$.

The low productivity of declining sites is confirmed by the fact that radial growth as a function of cambial age was consistently lower there than in non-declining sites (Fig. 6.4). The most defoliated trees from declining sites also tended to show less sapwood area $\left(r_{s}=-0.26, P<0.05\right)$. Declining sites were also those where more releases were detected since we found a significant positive relationship $\left(r_{s}=0.88, P<0.001\right)$ between the stand mean defoliation and the average number of releases per tree (Fig. 6.5a). For instance, 58\% of defoliated (crown defoliation $>50 \%$ ) trees from declining sites showed at least two releases before the 1980 s, whereas only $35 \%$ of trees without defoliation from non-declining sites did (Fig. 6.5b). 
(a)

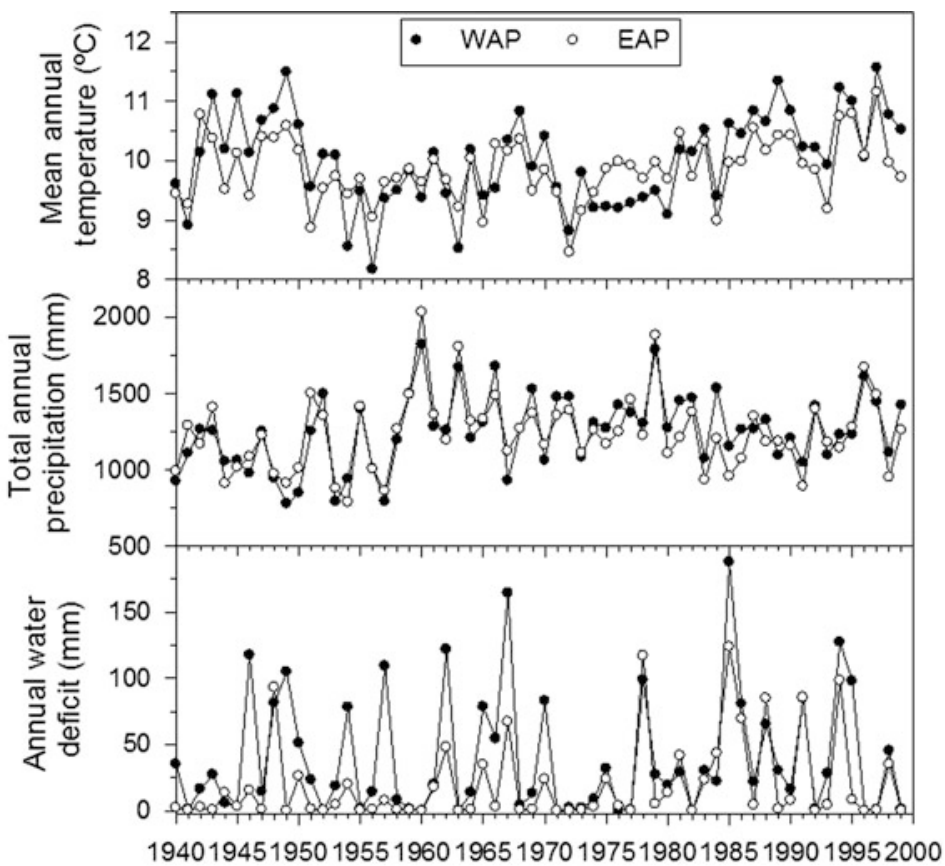

Year

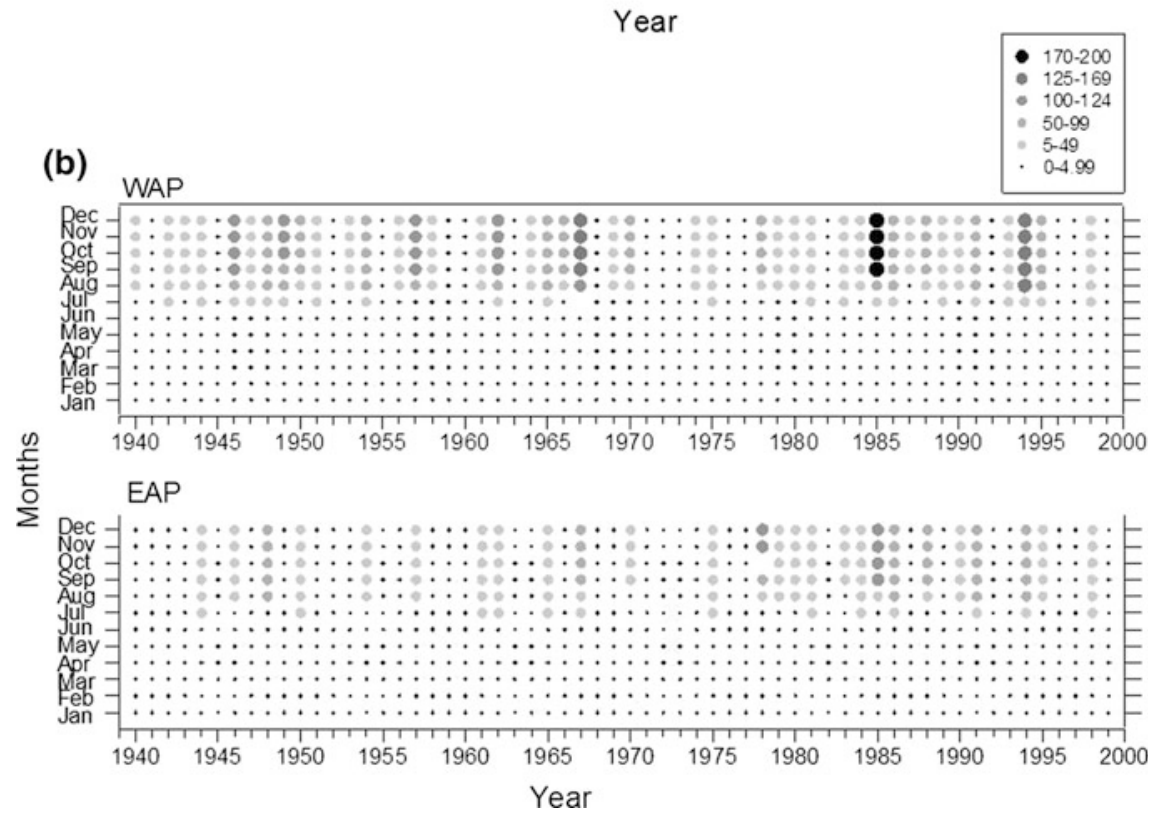

Fig. 6.2 Climatic variability during the 1940-1999 period for the two homogeneous climatic sub-regions: western (WAP) and eastern (EAP) Aragón Pyrenees. a Mean annual temperature, total annual precipitation and annual water deficit. b Cumulative monthly water deficits (the scale is in $\mathrm{mm}$ ) 

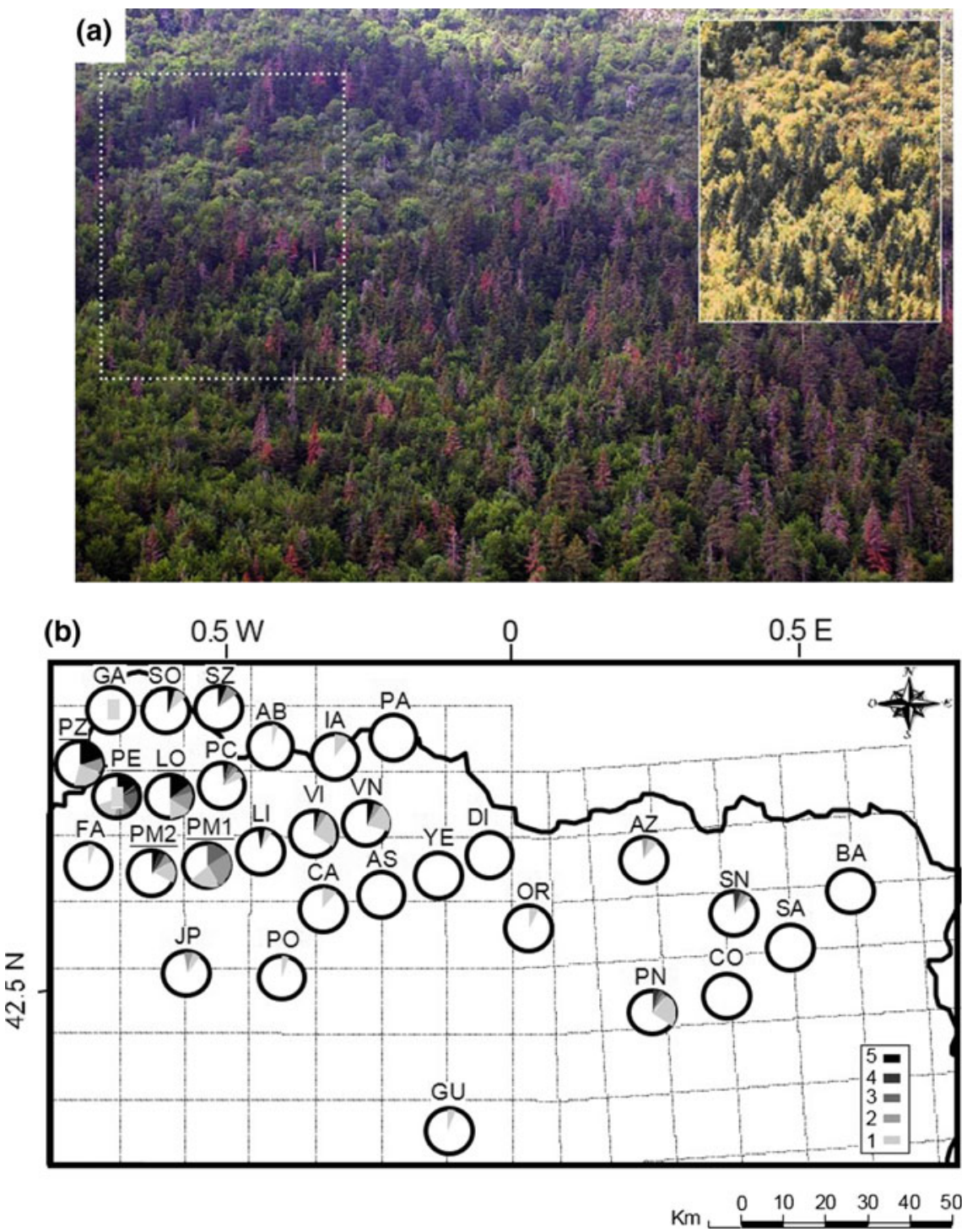

Fig. 6.3 Local and regional aspects of dieback across the Aragón Pyrenees, NE Spain. a View of a declining silver-fir stand situated in Paco Ezpela (abbreviated as PE). Red and defoliated trees are declining silver firs. The dark- and clear-green trees are healthy firs or pines and beeches, respectively. Note also the logged areas in the upper area of the image. The photograph was taken in June 2006, and the upper inset photograph corresponding to the area outlined by dashed line was taken in August 2001. Forest dieback has been widespread on this site since 1986. b Geographical patterns of crown defoliation in Aragón silver-fir forests. The graph shows the percentage of trees in each stand with different defoliation levels (class (1) 11-25\% crown defoliation; (2) 26-50\%; (3) 51-75\%; (4) 76-90\%; (5) >91\%, dead tree). Sites' codes are as in Fig. 6.1. Declining sites correspond to underlined codes (sites with more than $25 \%$ trees with crown defoliation $>50 \%$ ). The grid corresponds to $10 \mathrm{~km}^{2} \times 10 \mathrm{~km}^{2}$ 
Fig. 6.4 The mean radial growth of silver-fir trees from declining and non-declining sites according to the cambial age of tree-ring formation. The smoothed growth curves (grey lines) were obtained using a loess function with a (span) 0.1 smoothing parameter

Fig. 6.5 Declining sites were characterised by defoliated trees with growth releases. a The positive relationship between the stand mean defoliation and the mean number of releases detected per tree for the 1900-1980 period. Defoliation classes are as in Fig. 6.3. b Characteristic radial-growth (basal area increment) patterns of declining silver-fir trees, which died recently, without (upper graph) and with (lower graph) releases previous to the 1980s dieback. The white symbols indicate releases
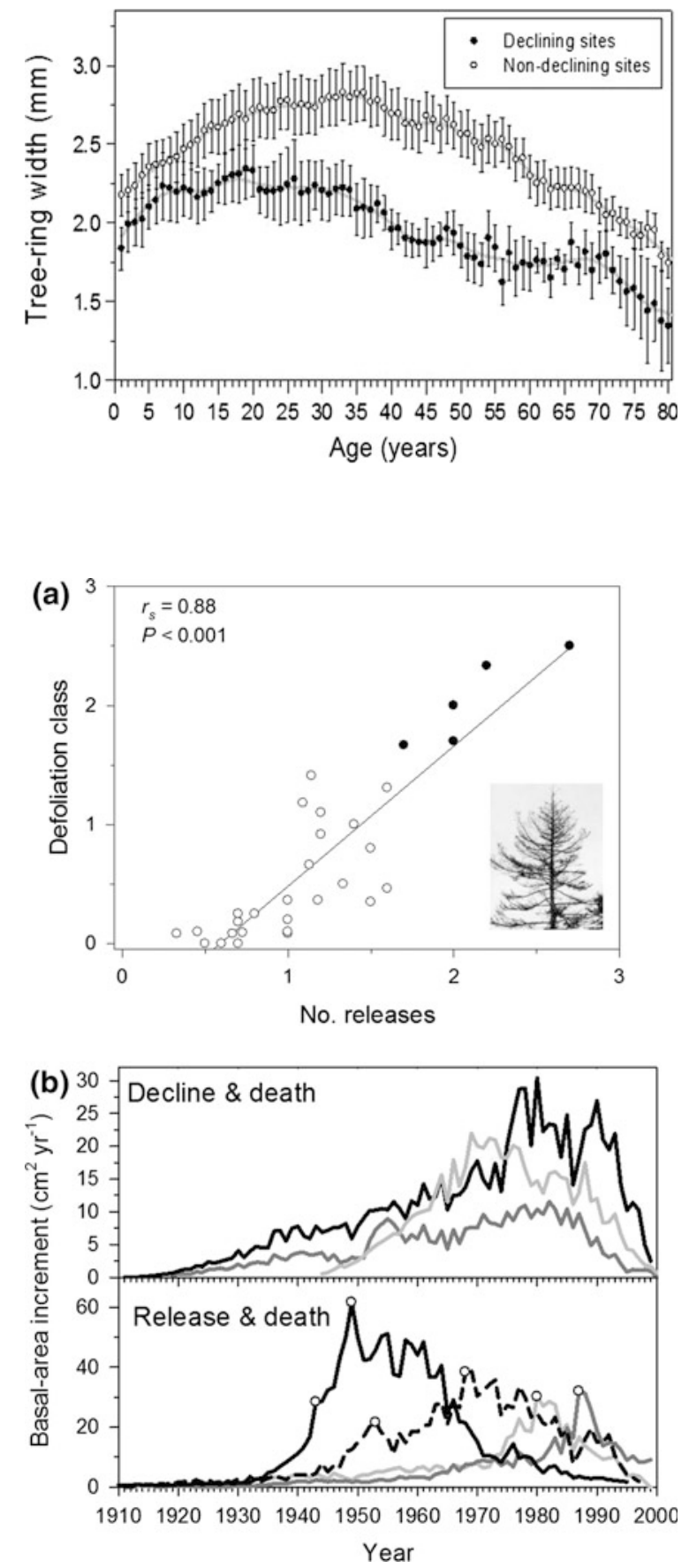


\subsection{Growth Trends of Silver Fir Indicate that Dieback is Predisposed by Past Logging}

Tree-ring width was significantly $(F=6.17, P=0.02)$ lower $(1.9 \pm 0.2 \mathrm{~mm})$ in declining than in non-declining $(2.7 \pm 0.1 \mathrm{~mm})$ sites. In addition, the percentage of growth variability explained by climate, calculated using multiple linear regressions, was significantly $(F=4.55, P=0.04)$ higher in declining $(52.3 \pm 1.6 \%)$ than in non-declining sites $(45.9 \pm 1.3 \%$; Table 6.1$)$. Such percentage was highest $(57 \%)$ in the southernmost sites (e.g. GU) which experience a greater drought stress than more northerly sites (Table 6.2). Thus, declining and southern sites showed a greater responsiveness to climatic stress than the rest of sites. However, no southern site showed signs of recent dieback such as severe defoliation or reduced radial growth. Crown defoliation was negatively associated with site longitude and elevation, and with tree dbh (Table 6.2).

The basal area increment of declining sites diverged from that of non-declining sites since the 1940s (Fig. 6.6). Nevertheless, both types of sites showed similar growth trends and short-term responses to climatic stress such as a very narrow ring in 1986 when the NGC reached minimum values everywhere. Such severe growth reduction was unprecedented during the twentieth century.

Declining sites showed a greater frequency of trees with releases than non-declining sites during several decades (e.g. the 1950s). It is inferred that such growth releases were the result of intense and widespread logging during that decade with many silver-fir forests affected across the Aragón Pyrenees (Cabrera 2001). In the Pyrenees, historical logging has mostly affected fast-growing and big trees thus promoting the persistence of small-diameter slow-growing trees, which might be more susceptible to drought stress. In agreement with this, we detected

Table 6.2 Relationships among the variables measured at the study silver-fir forests (values are Pearson correlation coefficients, excepting those related to defoliation that are Spearman coefficients)

\begin{tabular}{l|c|c|c|l|l|l|l}
\hline & Latitude & Longitude $^{\mathrm{a}}$ & Elevation & Defoliation & Dbh & Age & $\begin{array}{l}\text { Tree-ring } \\
\text { width }\end{array}$ \\
\hline Latitude & & & & & & & \\
\hline Longitude & $-0.57^{* *}$ & & & & & & \\
\hline Elevation & $-0.53^{* *}$ & $0.69 * *$ & & & & & \\
\hline Defoliation & $0.42^{*}$ & $-0.43^{*}$ & $-0.52^{* *}$ & & & & \\
\hline Dbh & 0.20 & 0.04 & 0.20 & $-0.48^{*}$ & & & \\
\hline Age & $0.43^{*}$ & -0.17 & -0.20 & -0.02 & 0.10 & & \\
\hline $\begin{array}{l}\text { Tree-ring } \\
\text { width }\end{array}$ & -0.14 & 0.13 & 0.29 & -0.33 & $0.63^{* *}$ & $-0.65^{* *}$ & \\
\hline Climate $\mathrm{R}^{2}$ & $-0.42^{*}$ & -0.20 & -0.14 & 0.13 & -0.33 & -0.24 & -0.08 \\
\hline
\end{tabular}

Defoliation refers to the percentage of trees in each stand with more than $50 \%$ crown defoliation.

Significance levels: $* 0.01<P \leq 0.05, * * P \leq 0.01$

${ }^{a}$ Negative and positive longitude values correspond to western and eastern sites, respectively 
Fig. 6.6 Trends in basal area increment of declining and non-declining silver-fir stands (a), mean negative growth changes (b), and frequency of trees showing releases $(\mathbf{c})$. Releases were defined as those years with growth changes greater than $75 \%$, respectively. The sample size is displayed in the upper graph. The smoothed curve in the upper graph (grey line) shows the long-term trend of basal area increment for all trees and was obtained using a loess function with a 0.1 span. The dark-grey area in the lower graph shows the common percentage of trees showing releases in both types of stands (a)

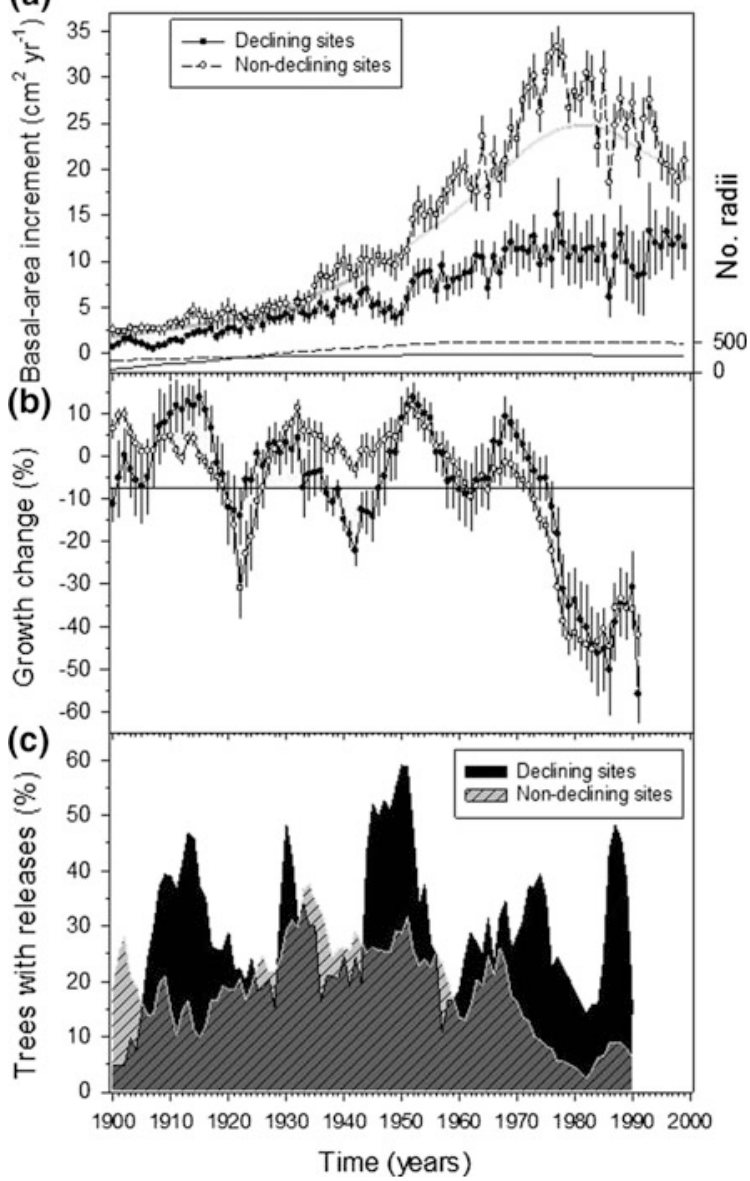

that tree dbh and growth along the cambial age of a tree were consistently lower in declining than in non-declining sites (Fig. 6.4). Other factors may explain why logging increases the sensitivity of silver fir to drought stress. For instance, there may be a boost in resources after logging, usually expressed as a growth release, which favours the acquisition of hydraulic traits (e.g. tracheids with wider lumen area) that increase hydraulic conductivity but also make trees more prone to drought damage. Logging is also related to the presence of root-rot fungi, but their abundance was not greater in declining than in non-declining Pyrenean sites (Oliva and Colinas 2007; Sangüesa-Barreda et al. 2015). Lastly, mistletoe infestation and insects whose outbreaks cause punctual silver-fir defoliation (e.g. Epinotia subsequana) have been identified in some affected forests, but they are not considered the primary drivers of silver-fir dieback but secondary factors contributing to tree death (Camarero et al. 2002, 2003, 2011). 
Reams and Huso (1990) also noted that declining red spruce stands in Maine were released one to three decades before dieback started. Historical logging may thus have caused sudden changes in the growth dynamics of surviving trees leading to drought-induced hydraulic failure. Also, microclimatic conditions (e.g. air and soil humidity) change drastically in logged open stands as compared with closed forests which may also affect silver-fir performance (Aussenac 2002). For instance, silver-fir defoliation increases in habitats with low soil-water holding capacity (Thomas et al. 2002). The 1980s releases found only in the declining sites were caused by the felling of dying trees, but many of the surviving trees did not improve their growth in the long term and, in many cases, died. These facts suggest that their performance was permanently affected by drought stress leading to an irreversible reduction in growth and suggesting a loss in stomatal regulation of declining trees despite the recent rise in atmospheric $\mathrm{CO}_{2}$ concentrations (Linares and Camarero 2012). Additional research is required to establish the links between soil-water availability, growth trends and dieback if these processes are to be used as monitors of the effects of climate warming on mountain forests.

\subsection{Climate-Growth Associations: The Critical Role Played by Late-Summer Water Deficit}

Silver-fir growth was enhanced by wet spring conditions and by cool and wet conditions during the summer prior to tree-ring formation (Fig. 6.7a). The first two axes of the PCA based on the correlation coefficients between climatic variables and site chronologies accounted for $26.7 \%$ and $17.0 \%$ of the total variance, respectively, (Fig. 6.7b). These analyses detected a positive and stronger response of tree growth in declining than in non-declining sites to current June precipitation, and a lower response to previous September precipitation and February temperature (negative relationship). The positive effect of current June (previous September) precipitation on growth in declining sites was significantly stronger (lower) than in non-declining sites (June, $F=6.57$; September, $F=6.30, P<0.02$ in both cases). The cumulative water deficits of the previous spring and the current growing season (JanuaryMay) were also negatively related to growth in declining sites, and these effects were more marked westwards. Silver-fir growth was also negatively (positively) associated with higher September (April) temperatures of the previous (current) year, and this association increased eastwards (westwards).

Climate-growth relationships were unstable through time since most growth-climate relationships changed in the 1980s according to moving correlations functions (Fig. 6.8). The negative influence of previous February and September temperatures and the positive influence of previous September precipitation on silver-fir growth strengthened since 1985 in the non-declining sites, whereas the positive influence of current July precipitation decreased. Declining sites showed a similar temporal instability of their growth-climate relationships, 
(a)
$\bullet$ Negative $\square$ Positive

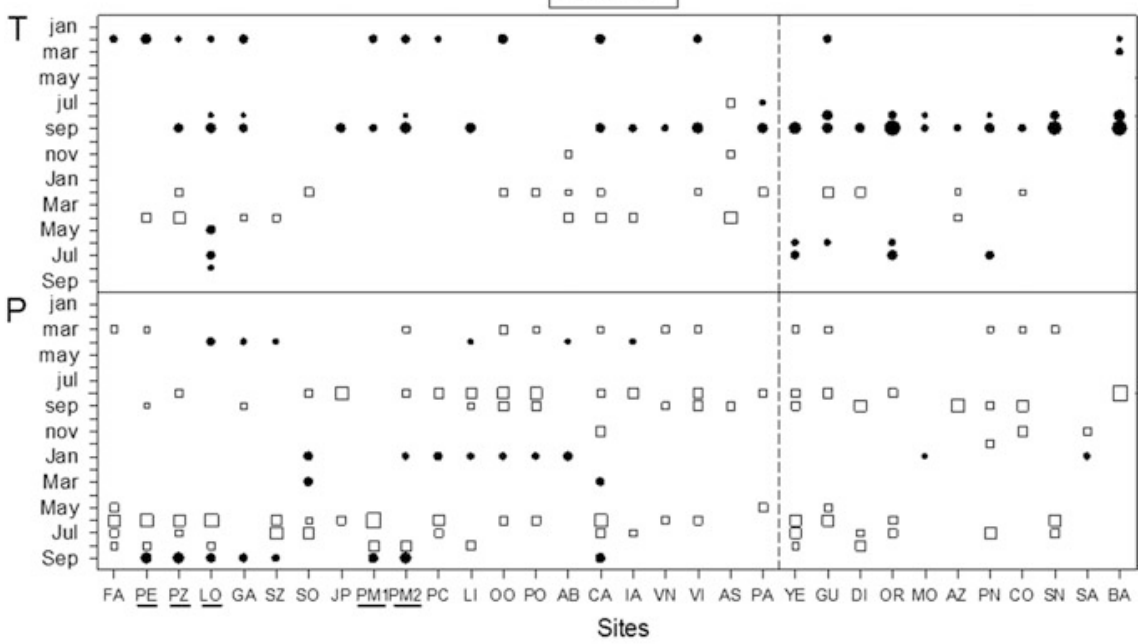

(b)

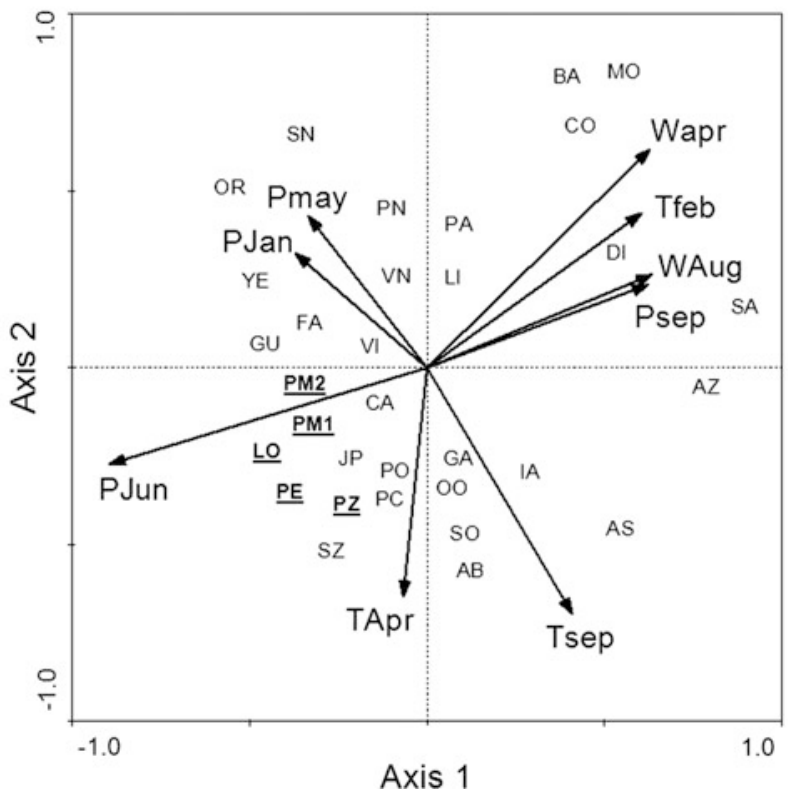


4Fig. 6.7 Climate-growth relationships in Pyrenean silver-fir forests. a The upper graphs show the significant $(P<0.05)$ bootstrap correlation coefficients calculated between monthly climatic data ( $T$ mean temperature; $P$ total precipitation) and the residual chronologies for the period 1950 1999. The strength of the correlation is indicated by the size of the symbol. Open squares indicate a positive correlation, and solid circles indicate a negative correlation. The months studied go from previous January to current September (months abbreviated by capital letters correspond to the year of tree-ring formation). The climatic data were calculated for the two climatic sub-regions (Western and Eastern Aragón Pyrenees), which are divided by the vertical dashed line. The sites are arranged from the west (left) to the east (right). The codes of declining sites are underlined. b Relative positions of silver-fir correlation functions based on the first two components of a Principal Component Analysis (axes 1 and 2 correspond to the first and second Principal Components, respectively) calculated on the matrix of climate-growth correlations shown in (a). Only the most significant climatic variables (arrows) are represented, and they are abbreviated using a three-letter code. Climatic variables starting with "W" refer to cumulative monthly water deficit (e.g. WAug, cumulative water deficit from January up to August of the year of growth). The months studied go from previous January to current September (months abbreviated by lower-/ uppercase letters correspond to the previous/current year of tree-ring formation; e.g. TApr stands for April temperature of the year of tree-ring formation). The climatic data were calculated for the two climatic sub-regions (Western and Eastern Aragón Pyrenees). Declining sites are shown as underlined bold codes

but with some characteristic features. First, the negative response to previous February temperatures became stronger during the late twentieth century in the declining sites, while a similar response to current July temperatures almost disappeared. Second, the positive response to previous March precipitation and current June precipitation also turned out to be stronger during the past decades. These changes coincided with warmer February conditions and the drier September conditions detected during the last decades.

The maximum growth reduction of silver fir occurred in 1986, which was preceded by the highest water deficit of the available climatic record. Defoliation and mortality were widespread in western low-elevation sites related to the warming trend since the 1980s and the outstanding water deficit in 1985, which were higher there than in the eastern study area. Macias et al. (2006) also suggested that silver fir is experiencing a greater late-summer drought stress in the Spanish Pyrenees and that the effects of water shortage on growth were more intense in low-elevation stands subjected to higher water deficit than elsewhere. The detected increase in drought stress was not only due to a decrease in precipitation, since similar dry periods occurred in the 1940s, and suggest a link with the 1980s warming (Vicente-Serrano et al. 2015) when the water-use efficiency of declining trees also increased sharply (Linares and Camarero 2012). The most pronounced warming in the western than in the eastern Aragón Pyrenees indicates that warming-induced drought stress triggered forest dieback westwards (Fig. 6.2). In addition, climate-growth relationships support a key role of late-summer water deficit controlling the silver-fir growth and dieback patterns in the Aragón Pyrenees (Figs. 6.3 and 6.7).

These results agree with dendroecological studies which found that silver-fir growth is very sensitive to water deficit during August and September before ring formation, responding negatively to high temperatures in those months (Bert 1993; 
Rolland et al. 1999; Tardif et al. 2003). This fact is consistent with the low stomatal regulation of gas exchange in silver fir and its dieback in sites with high leaf-to-air vapour pressure difference in response to warmer air temperatures (Peguero-Pina et al. 2007; Vicente-Serrano et al. 2015). Other factors such as nitrogen deposition might also be involved as occurred in the Vosges, where silver-fir dieback was also related to acidification (Pinto et al. 2007). However, nitrogen deposition is much higher there than in the Aragón Pyrenees (de Vries et al. 2003), and most of the study sites were located on basic soils and showed N-NW exposure.

The negative response of silver-fir growth to the growing-season cumulative water deficit increased westwards and was more marked in declining than in non-declining sites. Radial growth was also enhanced by current June precipitation and this effect also increased westwards as summer precipitation decreased (Figs. 6.3 and 6.7). Accordingly, growth in the western declining sites was more constrained by climatic conditions during the year of tree-ring formation than in the eastern non-declining sites. However, growth in declining sites was also affected by distinctive factors such as the negative relationship with previous February temperature.

Contrastingly, an increasing response of growth to previous September climatic conditions eastwards was detected, whereas the negative (positive) relationship with temperature (precipitation) increased during the second half of the past century (Fig. 6.8). These results seem to be counter intuitive since the 1986 dieback onset in the western study area was preceded by an extremely dry and warm September. Indeed, 1985 was the year with lowest September precipitation in the western study area during the twentieth century, and such dryness was caused by the presence of two high pressures over the northern Atlantic.

In the second half of the past century, silver-fir growth was positively and significantly related to the Scandinavian $(r=0.41)$ and the North Atlantic Oscillation $(r=22)$ indices of the previous September and November, respectively. The associations with these two dominant modes of atmospheric variability in SW Europe (Sáenz et al. 2001) were unstable since the correlations with the Scandinavian index peaked in the 1967-1986 period, whereas the NAO effects have changed from positive to negative. This transition was clearer for the western declining sites than elsewhere which suggests some connection between atmospheric variability and silver-fir dieback (Camarero 2011). The lower responsiveness to previous September climate in the westernmost area was linked to an earlier worsening of late-summer conditions there, probably through an intensification of warming-induced drought stress.

The presented findings have implications for silver-fir growth and persistence near the rear xeric edge of the species' distribution area. First, the year-to-year variation in tree growth of silver fir has increased in the second half of the twentieth century in response to a greater warming-induced drought stress and the occurrence of more frequent dry spells in the last decades as compared with earlier more favourable conditions in the first half of the past century (Tardif et al. 2003). It is also evidenced that this instability also affected the associations between growth and atmospheric variability since 1950. Second, it is expected that, in some 


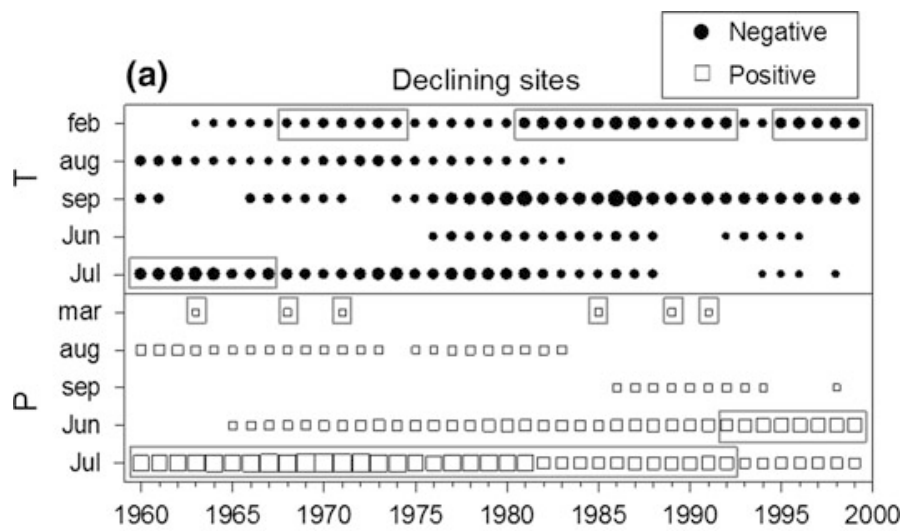

(b)

Non-declining sites

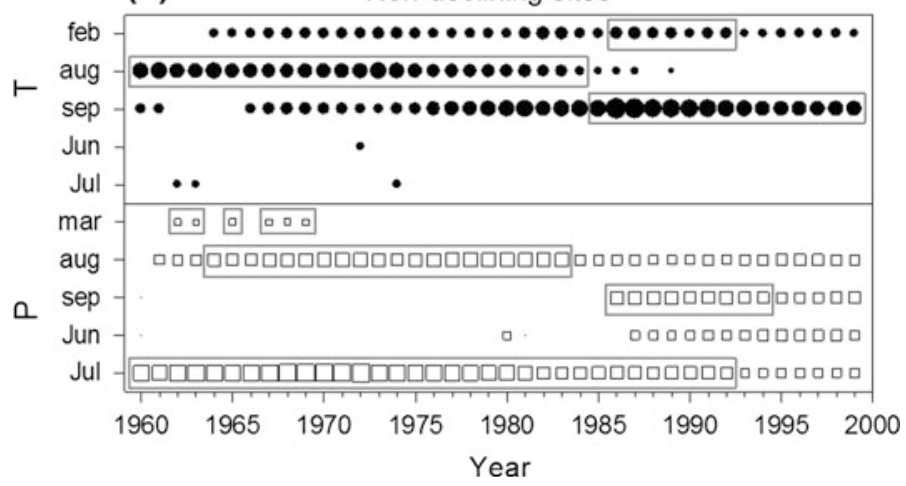

Fig. 6.8 Temporal instability of the climate-growth relationships for selected climatic variables. Moving-interval correlations functions show the significant $(P<0.05)$ bootstrap correlation coefficients based on the relationships between monthly climatic data ( $T$ mean temperature; $P$ total precipitation) and the mean chronologies for declining (a) and non-declining (b) sites. Months abbreviated by upper case letters correspond to the year of tree-ring formation, and months abbreviated by lower case letters correspond to the previous year. The years shown in the $x$-axis correspond to the last year of 50-year moving intervals lagged by 1 year $(1911-1960, \ldots, 1950$ 1999). The strength of the correlation is indicated by the size of the symbol. Open squares and solid circles indicate positive and negative correlations, respectively. Boxes enclose periods whose coefficients were significant $(P<0.05)$

low-elevation forests showing intense dieback, there will be a replacement of silver fir by beech and Scots pine in mesic and xeric sites, respectively. In fact, these findings reveal that declining sites were characterised by a higher basal area of beech and Scots pine than non-declining sites. We predict that the replacement of silver fir by co-occurring species will proceed faster in the western declining sites than eastwards. Finally, paleoecological evidence supports the contention that similar past abrupt climatic changes may have caused analogous drought-induced diebacks of tree species thus leading to rapid (ca. 500 years) changes in forest composition (Foster et al. 2006). 


\subsection{Lessons for Forest Use and Conservation}

The reconstructed history of growth releases in Pyrenean silver-fir forests suggests that dieback is the product of both predisposing and inciting factors (sensu Manion 1981) such as historical logging and warming-induced drought stress, respectively. Historical land-use changes have persistent effects on forest dynamics on decadal and even millennial time scales (Dupouey et al. 2002). However, historical legacies have not always been considered when explaining the causes of forest dieback; although several authors have illustrated how changes in management cause over-stocking and increase tree-to-tree competition for water making tree species, including firs, more susceptible to drought-induced damage (Becker et al. 1989; see some cases in the reviews by Allen et al. 2010, 2015).

The Pyrenean silver-fir dieback was triggered by pronounced late-summer water deficit (inciting factor) due to the rapid temperature rise observed in the Aragón Pyrenees since the 1980s. Historical logging is the most likely predisposing factor of this dieback process. The geographic pattern of forest dieback was a response to a regional climatic gradient with decreasing summer precipitation westwards, whereas dieback and crown defoliation and growth decline were highest in marginal low-elevation sites. Declining stands were characterised by being mixed forests with silver-fir trees of low size and growth rate. Silver-fir growth is becoming more dependent on previous September climatic conditions which may be connected with changing modes of atmospheric variability affecting the Iberian climate. Finally, I partly concur with Auclair (2005) that some dieback cases might be regarded as an additional disturbance factor of forest dynamics. However, both historical management and warming-induced drought stress are altering these dynamics. First, management might set the stage for forest dieback through the selection of particular trees or cohorts highly vulnerable to climatic stress. Second, inciting climatic stressors as warming-related droughts may become more frequent in a warmer world. Thus, the recurrence and severity of forest dieback episodes may be exacerbated leading to unprecedented growth drops outside the historical range of growth variability (sensu Veblen 2003).

To manage mountain forests in a more sustainable way so as to preserve biodiversity and provide ecosystem services including timber production it must be considered that their past use and history constrain their current structure and how they will respond to climate warming. Mountain forests are erroneously perceived as intact and wild ecosystems, but they have been shaped by centuries of exploitation, at least in Europe. If this past use has lead to uniform stands of trees vulnerable to climate warming, more dieback processes are expected across southern European mountains holding the southernmost limits of several tree species as is the case of silver fir in the Pyrenees (Gazol et al. 2015). A more sustainable use and conservation of mountain forests will require managing their structure to make them more resilient and less vulnerable to climate warming. Such management should consider the enhancement of functional and structural diversities which can contribute to increasing forest resilience and promote the 
post-drought recovery of the most affected forests (Gazol and Camarero 2016). Achieving such effective management measures to prevent or buffer some of the adverse effects of drought-induced dieback or to enhance forest resilience is a challenge for managers and researchers.

\section{References}

Allen CD, Breshears DD, McDowell NG (2015) On underestimation of global vulnerability to tree mortality and forest die-off from hotter drought in the Anthropocene. Ecosphere 6:129

Allen CD, Macalady AK, Chenchouni H, Bachelet D, McDowell N, Vennetier M, Kitzberger T, Rigling A, Breshears DD, Hogg EH, Gonzalez P, Fensham R, Zhang Z, Castro J, Demidova N, Lim J-H, Allard G, Running SW, Semerci A, Cobb N (2010) A global overview of drought and heat-induced tree mortality reveals emerging climate change risks for forests. For Ecol Manag 259:660-684

Auclair AND (2005) Patterns and general characteristics of severe forest dieback from 1950 to 1995 in the northeastern United States. Can J For Res 35:1342-1355

Aussenac G (2002) Ecology and ecophysiology of circum-mediterranean firs in the context of climate change. Ann For Sci 59:823-832

Barry RG (2008) Mountain weather and climate. Cambridge University Press, Cambridge, UK

Becker M, Landmann G, Lévy G (1989) Silver fir decline in the Vosges mountains (France): role of climate and silviculture. Water Air Soil Pollut 48:77-86

Bert GD (1993) Impact of ecological factors, climatic stresses, and pollution on growth of the silver fir (Abies alba) in the Jura mountains: an ecological and dendrochronological study. Acta Oecol 14:229-246

Bigler C, Braker OU, Bugmann H, Dobbertin M, Rigling A (2006) Drought as an inciting mortality factor in Scots pine stands of the Valais, Switzerland. Ecosystems 9:330-343

Bonan GB (2008) Forests and climate change: forcings, feedbacks, and the climate benefits of forests. Science 320:1444-1449

Breshears DD, Allen CD (2002) The importance of rapid, disturbance-induced losses in carbon management and sequestration. Glob Ecol Biogeogr 11:1-5

Cabrera M (2001) Evolución de abetares del Pirineo aragonés. Cuadernos de la Sociedad Española de Ciencias Forestales 11:43-52

Camarero JJ (2011) Direct and indirect effects of the North Atlantic Oscillation on tree growth and forest decline in northeastern Spain. In: Vicente-Serrano SM, Trigo RM (eds) Hydrological, socioeconomic and ecological impacts of the north atlantic oscillation in the mediterranean region. Advances in global change research, vol 46. Springer, pp 129-152

Camarero JJ, Padró A, Martín-Bernal E, Gil-Pelegrín E (2002) Aproximación dendroecológica al decaimiento del abeto (Abies alba Mill.) en el Pirineo aragonés. Montes 70:26-33

Camarero JJ, Martín-Bernal E, Gil-Pelegrín E (2003) The impact of a needleminer (Epinotia subsequana) outbreak on radial growth of silver fir (Abies alba) in the Aragón Pyrenees: a dendrochronological assessment. Dendrochronologia 21:1-10

Camarero JJ, Bigler C, Linares JC, Gil-Pelegrín E (2011) Synergistic effects of past historical logging and drought on the decline of Pyrenean silver fir forests. For Ecol Manag 262:759-769

Camarero JJ, Gazol A, Sangüesa-Barreda G, Oliva J, Vicente-Serrano SM (2015) To die or not to die: early-warning signals of dieback in response to a severe drought. J Ecol 103:44-57

Cook ER, Krusic PJ (2005) Program Arstan, a tree-ring standardization program based on detrending and autoregressive time series modeling, with interactive graphics. Tree-Ring Laboratory, Lamont Doherty Earth Observatory, Columbia University, Palisades, NY 
de Vries W, Reinds GJ, Vel E (2003) Intensive monitoring of forest ecosystems in Europe-2: atmospheric deposition and its impacts on soil solution chemistry. For Ecol Manag 174:97-115

Dupouey JL, Dambrine E, Laffite JD, Moares C (2002) Irreversible impact of past land use on forest soils and biodiversity. Ecology 83:2978-2984

Foster DR, Oswald WW, Faison EK, Doughty ED, Hansen BCS (2006) A climatic driver for abrupt mid-Holocene vegetation dynamics and the hemlock decline in New England. Ecology 87:2959-2966

Fritts HC (1976) Tree rings and climate. Academic Press, London, UK

Gazol A, Camarero JJ (2016) Functional diversity enhances silver fir growth resilience to an extreme drought. J Ecol 104:1063-1075

Gazol A, Camarero JJ, Gutiérrez E, Popa I, Andreu-Hayles L, Motta R, Nola P, Ribas M, Sangüesa-Barreda G, Urbinati C, Carrer M (2015) Distinct effects of climate warming on populations of silver fir (Abies alba) across Europe. J Biogeogr 42:1150-1162

Holmes RL (1983) Computer-assisted quality control in tree-ring dating and measurement. Tree-Ring Bull 43:69-78

Kirby KJ, Watkins C (eds) (1998) The ecological history of European forests. CABI, Wallingford, UK

Kohler T, Wehrli A, Jurek M (eds) (2014) Mountains and climate change: a global concern. Sustainable mountain development series. CDE-SDC, Bern, Switzerland

Linares JC, Camarero JJ (2012) From pattern to process: linking intrinsic water-use efficiency to drought-induced forest decline. Glob Change Biol 18:1000-1015

Linares JC, Camarero JJ, Carreira JA (2009) Interacting effects of climate and forest-cover changes on mortality and growth of the southernmost European fir forests. Glob Ecol Biogeogr 18:485497

Macias M, Andreu L, Bosch O, Camarero JJ, Gutiérrez E (2006) Increasing aridity is enhancing silver fir (Abies alba Mill.) water stress in its south-western distribution limit. Clim Change 79:289-313

Manion PD (1981) Tree disease concepts. Englewood Cliffs, Prentice Hall, NJ, USA

McDowell N, Pockman WT, Allen CD, Breshears DD, Cobb N, Kolb T, Plaut J, Sperry J, West A, Williams DG, Yepez EA (2008) Mechanisms of plant survival and mortality during drought: why do some plants survive while others succumb to drought? New Phytol 178:719-739

Müller EHR, Stierlin HR (1990) Sanasilva tree crown photos with percentages of foliage loss. Swiss Federal Institute for Forest, Snow and Landscape Research, Birmensdorf, Switzerland

Nowacki GJ, Abrams MD (1997) Radial-growth averaging criteria for reconstructing disturbance histories from presettlement-origin oaks. Ecol Monogr 67:225-249

Oliva J, Colinas C (2007) Decline of silver fir (Abies alba Mill.) stands in the Spanish Pyrenees: role of management, historic dynamics and pathogens. For Ecol Manag 252:84-97

Pedersen BS (1999) The mortality of Midwestern overstory oaks as a bioindicator of environmental stress. Ecol Appl 9:1017-1027

Peguero-Pina JJ, Camarero JJ, Abadía A, Martín E, González-Cascón R, Morales F, Gil-Pelegrín E (2007) Physiological performance of silver-fir (Abies alba Mill.) populations under contrasting climates near the south-western distribution limit of the species. Flora 202:226-236

Pinto PE, Gégout J-C, Hervé J-C, Dhôte J-F (2007) Changes in environmental controls on the growth of Abies alba Mill. in the Vosges Mountains, north-eastern France, during the 20th century. Glob Ecol Biogeogr 16:472-484

Reams GA, Huso MMP (1990) Stand history: an alternative explanation of red spruce radial growth reduction. Can J For Res 20:250-253

Rolland C, Michalet R, Desplanque C, Petetin A, Aime S (1999) Ecological requirements of Abies alba in the French Alps derived from dendro-ecological analysis. J Veg Sci 10:297-306

Sáenz J, Rodríguez-Puebla C, Fernández J, Zubillaga J (2001) Interpretation of interannual winter temperature variations over Southwestern Europe. J Geophys Res 106:20641-20652

Sangüesa-Barreda G, Camarero JJ, Oliva J, Montes F, Gazol A (2015) Past logging, drought and pathogens interact and contribute to forest dieback. Agric For Meteorol 208:85-94 
Skelly JM, Innes JL (1994) Waldsterben in the forests of Central Europe and Eastern North America: Fantasy or reality? Plant Dis 78:1021-1032

Suarez ML, Ghermandi L, Kitzberger T (2004) Factors predisposing episodic drought-induced tree mortality in Nothofagus - site, climatic sensitivity and growth trends. J Ecol 92:954-966

Tardif J, Camarero JJ, Ribas M, Gutiérrez E (2003) Spatiotemporal variability in tree ring growth in the Central Pyrenees: climatic and site influences. Ecol Monogr 73:241-257

Thomas AL, Gegout JC, Landmann G, Dambrine E, King D (2002) Relation between ecological conditions and fir decline in a sandstone region of the Vosges mountains (northeastern France). Ann For Sci 59:265-273

van Mantgem PJ, Stephenson NL (2007) Apparent climatically induced increase of tree mortality rates in a temperate forest. Ecol Lett 10:909-916

Veblen TT (2003) Historic range of variability of mountain forest ecosystems: concepts and applications. Forest Chron 79:223-226

Vicente-Serrano SM, Camarero JJ, Zabalza J, Sangüesa-Barreda G, López-Moreno JI, Tague CL (2015) Evapotranspiration deficit controls net primary production and growth of silver fir: implications for circum-mediterranean forests under forecasted warmer and drier conditions. Agric For Meteorol 206:45-54

Vigo J, Ninot JM (1987) Los Pirineos. In: Peinado Lorca M, Rivas-Martínez S (eds) La vegetación de España. Publicaciones de la Universidad de Alcalá de Henares, Alcalá de Henares, Spain, pp 351-384

Open Access This chapter is licensed under the terms of the Creative Commons Attribution 4.0 International License (http://creativecommons.org/licenses/by/4.0/), which permits use, sharing, adaptation, distribution and reproduction in any medium or format, as long as you give appropriate credit to the original author(s) and the source, provide a link to the Creative Commons license and indicate if changes were made.

The images or other third party material in this chapter are included in the chapter's Creative Commons license, unless indicated otherwise in a credit line to the material. If material is not included in the chapter's Creative Commons license and your intended use is not permitted by statutory regulation or exceeds the permitted use, you will need to obtain permission directly from the copyright holder.

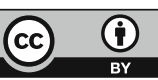

